\title{
The Effectiveness of Self Collection Strategy and Motivation on Students' English Vocabulary Mastery
}

\author{
Selfa Idriani. Bung Hatta University \\ selfaalanna@gmail.com
}

\begin{abstract}
This research purposed to prove whether Self Collection Strategy and Students' Motivation gives significant effect on the students' Vocabulary Mastery on English Subject. This research was quasi-experimental research by using the post test-only control group design. The population was the students at Economic Accountant Department Bung Hatta University in academic year of 2016/2017. The writer used cluster random sampling to select the samples. To collect the data, the researcher used vocabulary test. The data analyzed by using t-test and SPSS 16.0. The findings of this research showed that the mean score of students who were taught by using Self Collection Strategy was 84. The mean score of students who were taught by using memory strategy was 76. It means that Self Collection Strategy gave significant effect toward their vocabulary mastery on English Subject. The elements of Self Collection Strategy such as heterogeneous group, individual accountability and group reward are considered as the effort for the findings.
\end{abstract}

Key Note: Self Collection Strategy, Motivation, Vocabulary Mastery, English Subject

\section{Introduction}

Vocabulary is knowledge of words and word meaning. Vocabulary is an element of language which considered as one of important thing to be mastered by students in learning a foreign language. Specifically in learning English, there are many kinds of specific vocabularies that should be mastered by students.

Broadly defined, students can get various advantages in mastering English vocabulary. Specifically for students in Economic department Bung Hatta University, many literatures related with economic subject written in English. They will find it in their field work later. Moreover, MEA (Asean Economic Community) has been applied since december $31^{\text {st }}, 2015$. It will serve many field works and increase the quality of people life. Citra (2016) said in her Scientific orientation "untuk meraih berbagai peluang agar bisa berkompetensi dengan negara-negara lain di ASEAN, hal yang mutlak harus dikuasai dengan baik oleh angkatan kerja dan profesional dibidangnya adalah bahasa inggris". She said the most important thing to be mastered by freshgarduated in looking a job is English. Therefore, University should give serious attention in the process of teaching English.

Many problems faced by economic students in mastering English. The first problem, they are lack motivation. It is because teachers still apply traditional teaching strategy such as written, listen to the teacher explanation and doing exercises. Then, Several English lecturers who teach in Economic class. They said that students are lack of English vocabularies as a result they have problems in speaking, writing, and read literature in English. It also can be showed in their English score subject. The average score of their English subject is only 6,5. It means many of students get $\mathrm{C}$.

In accordance to the problem above teacher must be creative in teaching learning 
process. She/he must make teaching activity which can gain students' vocabulary mastery and students' motivation. It was assumed that Self Collection Strategy was more suitable to solve those problems.

Ruddel \& Sheare (2002:352) stated Self Collection Strategy help the students in identifying and learning terms that are the keys to a text or passage. Students' rationale for selecting certain words adds to their understanding of the process in learning. Students can build their vocabulary knowledge through active participation in "word discussion" and activities related to word learning. This strategy can help students to learn independently and to create teaching learning became active, to stimulate growth of word knowledge, to help students construct the meaning of unfamiliar words, and to understand the words faster with less boredom.

Considering the problems above, researcher was interested in doing research by using Self Collection Strategy to find out its effect toward students' vocabulary mastery at Economic Accountant Department Bung Hatta University.

\section{Vocabulary Self-Collection Strategy}

"The Vocabulary Self-Collection Strategy involves having students choose the words which want to learn, chat about their rationale for selecting words, and agree upon words for a classroom collection (Ruddell\& Shearer, 2002: 352-363)". This strategy is an effective approach to help students understand the meaning of new words, use them in conversation and writing, and make personal for authentic tasks and on a regular basis in their writing. Vocabulary SelfCollection Strategy enhances students' motivation and mastery in learning new words. Students' rationale for selecting certain words adds to their understanding of the process in learning. Students can build their vocabulary knowledge through active participation in "word discussion" and activities related to word learning.

According to Antonacci (2011: 88) "Vocabulary Self-Collection Strategy is an interactive-learning instructional strategy that promotes word consciousness, as students are actively engaged in identifying important words from their reading to share with members of their class". The strategy was first introduced by Haggard and has been adapted for various grade levels and instructional contexts. Students select words from their readings that are new and interesting, use the context and other resources to determine the meaning of the words, and nominate the words to be learned by others in the group or class. Lecturers using the vocabulary self-collection strategy as the process to collect the words, to provide guided practice within reading groups and other instructional contexts, and to offer consistent encouragement of students to use that strategy during independent reading. The major benefits of using Vocabulary Self-Collection Strategy are that students engage in their own learning, discover how to recognize unfamiliar or interested words from their readings, develop their vocabularies become familiar word.

Based on definitions above, it can be concluded that Vocabulary Self-Collection Strategy as procedure of vocabulary development to stimulate growth in word knowledge. This strategy has purposes to increase the internal motivation on vocabulary acquisition and development, to define the words 
more quickly and easily, to collect new words and enjoy in word learning.

\section{The Application of Vocabulary Self-Collection Strategy in Teaching Vocabulary}

Readence, et all (2001) state that "the purpose of Vocabulary Self-Collection Strategy is to help students generate a list of words to be explored and learned. It will improve their own prior knowledge and enhance their vocabulary". This strategy can be used to stimulate the students of word knowledge. Word list is selfgenerated, an internal motivation is utilized. This strategy can help students become fascinated with language and increased their enjoyment of the subject. Vocabulary Self-Collection Strategy involves everal steps: selecting the words, defining the words, finalizing the word lists, and extending word knowledge.

Finally, Coelho (2007) states "the purpose of Vocabulary Self-Collection Vocabulary which students learn to gather information about a foreign word or concept based on context clues and reference guides". This strategy is especially helpful for English-Language Learners as explanation between words and word meanings. All students can gain a greater understanding of texts and improve their long-term acquisition of vocabulary as it relates to academic texts.

Based on explanation above, it can be concluded that the purpose of Vocabulary SelfCollection Strategy to teach the students how to make decision about the important of concepts and how to use context to determine word meaning, and to promote the long term acquisition of language in a content area. This vocabulary activity is designed to help students work together to determine words don't know from the text, and the words can't directly decide what the words mean through context. In doing this activity, working in groups, students will be able to determine the meaning of many words by context, but will also be able to decide what words are more important than others.

The problem of the research can be formulated as follows:

1) Do the students' vocabulary mastery that is taught by Vocabulary Self-Collection Strategy better than memory strategy?

2) Do the students' vocabulary mastery with higher motivation that is taught by Vocabulary Self-Collection Strategy better than students' vocabulary mastery with higher motivation that is taught by memory strategy?

3) Do the students' vocabulary mastery with lower motivation that is taught by Vocabulary Self-Collection Strategy better than students' vocabulary mastery with lower motivation that is taught by memory strategy?

4) Is there any interaction between both strategies (Vocabulary Self-Collection Strategy and memory strategy) and motivation toward students' vocabulary mastery?

The purposes of this research are:

1) To find out whether the students' vocabulary mastery that are taught by Vocabulary Self-Collection Strategy have better than those taught by memory strategy.

2) To find out wether the students' vocabulary mastery with higher motivation that is taught by Vocabulary Self-Collection Strategy better than students' vocabulary 
mastery with higher motivation that is taught by memory strategy?

3) To find out wether the students' vocabulary mastery with lower motivation that is taught by Vocabulary SelfCollection Strategy better than students' vocabulary mastery with lower motivation that is taught by memory strategy?

5) To find out wether there is any interaction between both strategies (Vocabulary SelfCollection Strategy and memory strategy) and motivation toward students' vocabulary mastery?

\section{Research Design}

This research was quasi-experimental research. Related to this idea, the researcher investigated the effect of independent variable: Self Collection Strategy and the dependent variables namely Vocabulary mastery as learning achievement. The design of this research was the posttest-only control group design. The design of the research could be seen in the following formula:

$\begin{array}{lll}\text { R1 } & X & \text { O1 } \\ \text { R2 } & - & \text { O2 }\end{array}$

Where:

$\mathrm{R} 1=$ Random assignment of groups (experiment)

R2 = Random assignment of groups (control)

$\mathrm{X}=$ Self Collection Strategy for Experiment group

- $\quad$ = memory Strategy (conventional technique)

$\mathrm{O} 1=$ Post-test of experiment group

$\mathrm{O} 2$ = Post-test of control group
In the process of teaching, the differences between experimental group and control group was only about the strategy used. The material and the time allocation of the two classes were the same.

\section{The Population of Sample}

The population of this research was students in Economic Accountant class of Bung hatta University 2016/2017. To conduct the research, the researcher ensured that the population was in normally and homogeneity distribution. Therefore, the researcher tested the normality, homogeneity and analysis of variance of the population from students' English test score. In this research, it needs two sample classes, control and experimental classes. The researcher was used cluster random sampling to choose the sample.

\section{Instrumentation}

Test of vocabulary mastery and questionnaire of motivation were the instruments. It was assigned in post-test after the treatment done. Before the test was assigned, the researcher consulted the instruments to the validators to know whether the instruments were valid or not. Then, researcher did the try out in another class (class $\mathrm{C}$ as respondent) to find out the validity and reliability of instruments.

The test must be tried out before it is used. It was aimed to known whether that instrument which would be used had met the criterion of a good test or not. Validity testing was done by compare $t_{\text {observed }}$ and $t_{\text {table }}$ from $t$ distribution with $\alpha=0.05$ and the degrees of freedom $\mathrm{df}=\mathrm{n}-1$ and the reliability of the test, the researcher was used Kuder_Richardson formula or called K-R-21 to measure the reliability of instrument. Formula K-R.21 was 
used to measure reliability of item (Arikunto, 2009: 230) as below:

$$
r_{i=\frac{k}{k-1}}\left\{1-\frac{M(K-M)}{K S_{t}^{2}}\right\}
$$

While counting the $\mathrm{M}$ (mean):

$$
\mathrm{M}=\frac{\sum X}{N}
$$

Where:

$$
\begin{aligned}
& M=\text { Mean } \\
& \sum=\text { Sum of } \\
& X=\text { Score in a distribution } \\
& N=\text { Number of students }
\end{aligned}
$$

Questionnaire was used to measure the students' motivation related to applying Vocabulary Self-Collection Strategy in teaching and learning process based on the indicators: Positive task orientation, Ego-involvvement, Need for achievement, High aspirations, goal orienation, perseverance, and Tolerance of ambiquity.

Validity of quistionare was measured by using Correlation Product Moment formula and SPSS 16.0. It has same procedure of validity the test. It included content and construct validity. Reliability is the degree of a test consistently measures what it should be measured (Gay, 2000: 169). It was analyzed by using SPSS 16.0 and Alpha Cronbach formula.

Alpha formula:

$$
r_{11}=\left(\frac{k}{k-1}\right)\left(1-\frac{\sum \sigma_{b}^{2}}{\sigma_{I}^{2}}\right)
$$

Where: $r_{11}=$ Reliability of instruments

$\sum \sigma_{b}^{2}=$ Sum of variance item

$$
\sigma_{I}^{2} \quad=\text { Total variance }
$$

$\mathrm{k}=$ Sum of item

\section{Hypothesis Testing}

Research hypothesis was tested is the null hypothesis (Ho) or the statistical hypothesis. Ho is the hypothesis which states that the mean score of students between the experimental and control classes are no different. Hypothesis other than the null hypothesis (Ho) is the alternative hypothesis (Ha), the hypothesis was accepted if the null hypothesis was rejected. The hypotheses in this study are as follows.

\section{First Hypothesis:}

$$
\begin{aligned}
& H_{0}: \mu B_{1}=\mu B_{2} \\
& H_{1}: \mu B_{1} \neq \mu B_{2}
\end{aligned}
$$

Where:

$\mu=$ Students' Vocabulary Mastery

$\mathrm{B}_{1}=$ Teaching by using Vocabulary Self-

Collection Strategy

$\mathrm{B}_{2}=$ Memory Strategy

\section{Second Hypothesis:}

$$
\begin{aligned}
& H_{0}: \mu A_{1}=\mu A_{2} \\
& H_{1}: \mu A_{1} \neq \mu A_{2}
\end{aligned}
$$

Where:

$\mu=$ Students' vocabulary mastery

$\mathrm{A}_{1}=$ Students who have high motivation that are taught by using Vocabulary SelfCollection Strategy

$\mathrm{A}_{2}=$ Students who have low motivation that are taught by using Vocabulary SelfCollection Strategy

\section{Third Hypothesis:}

$$
\begin{gathered}
H_{0}: \mu A_{1} B_{1}=\mu A_{1} B_{2}=\mu A_{2} \\
B_{1}=\mu A_{2} B_{2} H_{1}:
\end{gathered}
$$


One of averages are not same

Where:

$\mu=$ Students' vocabulary mastery

$\mu B_{1} A_{1}=$ Students' vocabulary mastery who

have high motivation that are taught

by using Vocabulary Self-Collection

Strategy.

$\mu B_{1} A_{2}=$ Students' vocabulary mastery who

have low motivation that are taught by using Vocabulary Self-Collection Strategy.

$\mu B_{2} A_{1}=$ Students' vocabulary mastery who have high motivation that are taught by using memory strategy.

$\mu B_{2} A_{2}=$ Students' vocabulary mastery who have low motivation that are taught by using memory strategy.

\section{DISCUSSION}

The highest score of students' vocabulary mastery after got the treatment by using Vocabulary Self-Collection Strategy in experimental class was 84 , while the lowest score was 56 , the mean was 73.33 variance was 76.51 and standard deviation was 8.75. On the contrary, the control class by using memory strategy the highest score was 76, the lowest score was 44 , the mean was 59.20 the variance was 111.89, and the standard deviation was 10.58 .

This research was conducted for four meetings in experiment and control classes. The experiment class was given the treatment of Vocabulary Self-Collection Strategy while the control class was treated by memory strategy. After got the treatment, both classes were given the test. It was to know which one of them was more effective. Based on the test result and data analysis, it could be seen that students who were taught by Vocabulary Self-Collection Strategy got higher score than memory strategy.

\section{Hypotheses Testing}

Hypotheses testing of this research were done by t-test. The result of first hypothesis in this research showed that there is significant effect of students' vocabulary mastery which was taught through Vocabulary Self-Collection Strategy. As seen on the table below:

Table 3.1 Result of hypothesis 1

\begin{tabular}{|c|c|c|}
\hline \multirow{2}{*}{ Classification } & \multicolumn{2}{|c|}{ Class } \\
\cline { 2 - 3 } & Experiment & Control \\
\hline $\mathrm{N}$ & 30 & 30 \\
\hline $\bar{x}$ & 73.33 & 59.20 \\
\hline$S^{2}$ & 76.51 & 111.89 \\
\hline$S$ & 8.75 & 10.58 \\
\hline$t_{\text {score }}$ & \multicolumn{2}{|c|}{5.640} \\
\hline$t_{\text {table }}$ & \multicolumn{2}{|c|}{1.676} \\
\hline
\end{tabular}

The result of hypothesis testing was: $t_{\text {observed }} 5.640$ and $t_{\text {table }} 1.676$ with $\alpha=0.05$. Since $t_{\text {observed }}$ was higher than $t_{\text {table }}(\mathrm{To}>\mathrm{Tt})$, so null hypothesis (Ho) was rejected. It meant that there is significant effect of students' vocabulary mastery which was taught by using Vocabulary Self-Collection Strategy. This hypothesis has supported by Ruddel\& Shearer theories (2000), they stated that Vocabulary SelfCollection Strategy enhances students' achievement in learning new words. Students' rationale for selecting certain words adds to their understanding of the learning process. In this strategy, students worked in groups and be able to determined the meaning of many words in the context. In addition, the students are able to decide what words more important than others. 
Based on the hypothesis result, students' vocabulary mastery that had high motivation got higher score through Vocabulary Self-Collection Strategy. It can be seen from the mean score of both classes; experimental class was 78.50 and control class was 62.00 . The students could more improve their activeness in learning. Most students of high motivation were able to answer the questions. It was proved by their work sheet and the result of test. It can be concluded that the students who had high motivation was taught by using Vocabulary Self-Collection Strategy better than students who had high motivation was taught by using memory strategy. It has supported by Ruddel and Shearer (2000). They stated that Vocabulary Self-Collection Strategy enhances students' motivation and build their vocabulary knowledge through active participation in word discussion.

The result of hypothesis 3 showed that generally low motivated students' vocabulary mastery which was taught through Vocabulary Self-Collection Strategy was better than memory strategy. The mean score of experiment class was 64.50 while in control class was 47.00.It means that Vocabulary Self-Collection Strategy was gave significant effect of students' vocabulary mastery who had low motivation in experimental class.

Based on the analysis data of hypothesis result, it was stated that there was no interaction between both strategies and motivation toward students' vocabulary mastery. It could be seen from data analysis where $F_{\text {observed }}=0.70, F_{\text {table }}$ $=4.21$. it can be concluded that $\mathrm{Fo}<\mathrm{Ft}$, it means Ho was accepted, it could be said that there was no interaction between both strategies and motivation toward students' vocabulary mastery.

\section{Conclusion}

Based on the research finding and data analysis, it can be concluded that there is significant effect of students' vocabulary mastery which was taught through Vocabulary Self-Collection Strategy and memory strategy. In the first activity of Vocabulary Self-Collection Strategy, students were not so interested because they were still adapted with it. The result of their sheet showed that only few words that they were able to be understood. Beside that they made some mistakes in defining several words. In the second activity, the students were better than first activity. They were made fewer mistakes in defining the words. That condition was more improved in the third and fourth activity. Students were very interested in learning. Heterogeneous group, individual accountability and group reward are considered as the effort for the findings. This result related and conducted by Anhar's research (2010). He found that the students' score showed the progress of students' vocabulary mastery.

Vocabulary Self-Collection Strategy gave large opportunity for students to explore their ability. Students more activated in learning process and more motivated to read in order to get more information and knowledge. So they had much chance to exercise in mastering vocabulary. It was proved by their work sheet. They more understood the vocabulary at every meeting of Vocabulary Self-Collection Strategy activity.

Students in Vocabulary Self-Collection Strategy class became more activated than memory strategy class. Vocabulary SelfCollection Strategy made them to be easier in defining and extending the words. Beside that 
they can recognized the words that they had learnt well.

In conclusion, this strategy was an effective approach to help students understand the meaning of new words. The researcher would like to put forward some suggestions that may be useful for the lecturers especially the English lecturers in teaching English vocabulary. The researcher proposes some suggestions: Vocabulary Self-Collection Strategy can be applied in teaching learning process, especially if it purposes to improve students' achievement and motivation. For lecturer, in teaching vocabulary, it is better for English lecturer, applying Vocabulary Self-Collection Strategy. For students, it can motivate students to enrich and to learn English vocabulary. They can build their vocabulary knowledge through active participation in word discussion and can select certain words to their understanding of the learning process.

\section{REFERENCES}

Antonacci\& O' Callaghan. 2011. Promoting Literacy Development: 50 Research-Based Strategies for K-8 Learners (Online). Thousand Oaks : Sage Publications, Inc. (http://www.worldcat.org/title/promotingliteracy-development-50-research-basedstrategies-for-k-8-learners/oclc/670478765, download at 19 April 2017).

Anhar. 2010. "Teaching Vocabulary through Vocabulary Self-Collection Strategy to the Second Year Students of SMPN 2 Kuta in Academic Year 2010/2011". Unpublished Thesis. Bali: Universitas Bali.

Arikunto, S. 2009. Dasar-dasar Evaluasi Pendidikan Edisi Revisi. Jakarta: Bumi Aksara.

Coelho. 2007. Vocabulary Self-Collection Strategy (Online), (http://www.docjax.com/document/view.sht $\underline{\text { ml}}$ id $=323395 \&$ title $=$ Vocabulary $\% 20$ SelfCollection \%20Strategy $\% 20 \% 28$ VSS $\% 29 \%$
20The $\% 20$ Alchemist $\% 20$ by $\% 20$ Paulo $\% 20$, download at 19 April 2012).

Gay, L, R and Peter Airasian. 2000. Educational Research: Competencies for Analysis and Application. New Jersey: Prentice Hall.

Hasan, Citra Diana. 2016. Orasai ilmiah "Masyarakat ekonomi Asean tantangan dan peluang bagi bangsa Indonesia melalui Bahasa Inggris"

Richardson, et all. 2009. Reading to Learn in the Content Areas (Online). Canada: Wadsworth, Cengage Learning (Online), (http://books.google.co.id/books?id=F2Dj NkpwOwC\&pg=PT219\&lpg=PT219\&dq=v ocabulary+selfcollection+strategy+in+teach ing+vocabulary \&source $=$ bl\&ots $=$ AT5 fbCy YkO\&sig=oMDOIrgiiT6NSDBuNAMW7s 0wmg\&hl=id\&sa=X\&ei=TQG9T82dB47xr Qejy_nGDQ\&ved=0CGUQ6AEwBzgK\#v= onepage \&q=vocabulary $\% 20$ selfcollection $\%$ 20strategy\%20in\%20teaching\%20vocabula ry\&f=false, download January 2017).

Ruddell, M.R., \& Shearer, B.A. 2002. "Extraordinary," "tremendous," "exhilarating," "magnificent": Middle school at-risk students become avid word learners with the vocabulary self-collection strategy (VSS). Journal of Adolescent \& Adult Literacy, 45, 352-363. http://www.readwritethink.org/classroomresources/lesson-plans/choosing-chattingcollecting-vocabulary-296.html, download at 19 Januari 2017.

Readeance, Bean, \& Baldwin. 2001. Literacy Strategy Vocabulary Self-Collection Strategy(Online),(http://www.google.co.id/ search?q=vocabulary+self+collection+strat egy\&ie=utf-8\&oe $=$ utf8\&aq=t\&rls=org.mozilla:enUS:official\&client=firefox$\underline{\text { beta\&channel=fflb }}$, download at 19 April 2012). 